\title{
The Implementation of Environmental Care Character Education Based on Tri Hita Karana and Ecotourism at Elementary Schools in Nusa Penida, Bali
}

\author{
I Nyoman Indhi Wiradika \\ Graduate School \\ Universitas Negeri Yogyakarta \\ Yogyakarta, Indonesian \\ Indhiwiradika@gmail.com
}

\author{
Amat Jaedun \\ Graduate School \\ Universitas Negeri Yogyakarta \\ Yogyakarta, Indonesian \\ Jaedun@uny.ac.id
}

\begin{abstract}
This research aims to describe: (1) the implementation of environmental care character education based on Tri Hita Karana (THK), (2) the implementation of environmental care character education based on ecotourism. This research was conducted on Nusa Penida Island, Bali Province, by using qualitative descriptive method. The subject of this research was chosen purposively which consisted on headmasters, teachers, students, and tourism doers. The data was collected through the observation, deep interview, and documentation. The validity of data was done through data triangulation way. The process of data analysis consisted of three related steps, they were: data reduction, data display, and conclusion drawing. The results of this research showed two findings. First, the implementation of environmental care character education based on THK reffered to the aspects of parahayangan, pawongan and palemahan. Second, the implementation of environmental care character education based on ecotourism at Elementary School students at Nusa Penida and it also was implemented in some aspect such as environment, development, and experience.
\end{abstract}

Keywords-Environmental care, character education, Tri Hita Karana, Ecotourism, Elementary School

\section{INTRODUCTION}

Natural environmental care character is a fundamental aspect in the sustainable development. Education as a society character building institution has an important role to realize the character of environmental care. This thing was demonstrated by the Center for Curriculum at the Ministry of National Education which stated environmental care as one of the eighteen characteristics of education.

Environmental care character is decribed as attitudes and actions that always try to prevent damage to the surrounding natural environment by developing efforts in repairing the natural damage that has already occurred [1]. The implementation of environmental care character education has remained independently and does not involve its supporting components. Muhamin [2] considers that, students understand more about environmental education to a limited extention, without understanding the nature of how to preserve the natural environment.

The understanding of environmental problems cannot be separated from the habituation of social practices. The pattern of social behavior is important in relation to the natural environment. For Balinese people, binding rules such as traditional and religious teachings are things that cannot be negotiated. Thus, Sponsel [3] sees culture as the most decisive factor in human interaction with the environment.

People of Bali recognize Tri Hita Karana (THK) concept as the cultural product which is believed as three factors causing happiness. THK was firstly introduced at 1966 by Wayan Merta Suteja through the Badan Perjuangan Umat Hindu Dharma (BPUHD) or The Hindu Council. The initial components introduced by THK are Urip, Bhuwana and Manusa. Because the term THK was intensified, in 1969 at the Udayana University the THK concept was presented in a seminar by I Gusti Ketut Kaler known as the Parhyangan, Pawongan, and Palemahan.

Etimologicallly, the terminology of THK was obtained from Sanskrit which means three causes of happiness $($ Tri $=$ three, Hita $=$ prosperous, Karana $=$ cause). This terminology of THK was implemented as the taught for human to live harmoniously with god, with other humans and with the environment [4].

The internalization of the THK concept creates the practices in every area of the life of the people of Nusa Penida. The concept of THK can be seen clearly in the three environments, they are: (1) family environment in the family spatial and community such as: pemerajan called parhyangan, family members called pawongan, green open spaces along with buildings outside parhyangan are called palemahan, (2) the village environment is realized in the layout and village community which consist of: pura, which is called parhyangan, the village members are called pawongan, the green open space along with the buildings outside parhyangan are called palemahan and (3) the school environment is 
manifested in the school layout and community, they are: temples called parhyangan, students, teachers and employees are called pawongan, green open spaces and buildings outside Parhyangan are called palemahan. According to Sudira [5] the realization of THK at the school level is; parhyangan in the form of a school temple, the staff / staff are residents of the school as pawongan, the physical / member is the school area as palemahan.

THK in the education process in Nusa Penida is only manifested as a concept internalized by all school communities. Until now, THK has not been realized in a formal education programe. Culture as a conceptual tool to illustrate that at the core of the current environmental crisis is showed in the pattern of everyday culture that is interwoven through the most intimate and fundamental aspect. However, that, Anderson, Datta, Dyck, Kayira and McVittie [6] consider intervention at the cultural level in education inviting the excavation of all that is considered reasonably as the sound and legitimation in the collective experience of the society.

Besides the THK concept, Balinese people who are close to the tourism industry cannot be separated from natural activities. Urbanus and Febianti [7] explain that Bali's tourism development has a direct impact on the environment which is starting to increase the number of motorized vehicles, reduced water resources, and in the end, it leads the destruction of agricultural irrigation systems.

Ecotourism according to Nugroho [8] is a tourist travel activity that is professionally packaged, trained and contains elements of education, as an economic sector/ business, which takes and involves the cultural heritage, participation and welfare of residents and efforts to conserve natural resources and the environment.

Ecotourism as a concept born from the tourism industry has a close relationship with educational institutions. Thwaites, Lipscombe \& Smith [9] revealed that the concept of ecotourism was developed by the relationship between ecotourism as an industrial need, and an educational institution as a place to develop skills. Furthermore, Thwaites, Lipscombe \& Smith [10] emphasize the importance of interaction between ecotourism needs with educational institutions

James R. Kimmel [11] explains that ecotourism presents a great opportunity to be able to contribute to environmental education. Ecotourism development can support the implementation of contextual learning, because students are directly involved with the phenomena that occur in their daily lives, so that contextual learning can foster and develop an attitude of caring for the environment. Through ecotourism indirectly provides an opportunity for awareness of nature is a source of knowledge without limits to the formation of character caring for the natural environment.

Sharpley [12] proposes three main pillars for developing ecotourism, those are: (1) Environment, (2) Development and (3) Experience. The environment is oriented towards managing activities that contribute to the conservation of flora and fauna of natural areas. Development encourages the participation and control of local communities in developing tourism that provides sustainable socioeconomic benefits for residents. While experience provides opportunities for learning and meaningful meetings between tourists and the environment / local society.

Research results related to the concept of THK and Ecotourism are generally reviewed separately. Recent research conducted by Sudarsana [13] emphasized the optimization of the THK learning model in order to strengthen the character of elementary school students. Afriza, Kartika, Riyanti [14] emphasized the concept of ecotourism development based on economic principles, community participation, education and tourism. While in this study focuses on describing the implementation of environmental care character education based on the THK and Ecotourism concept at the elementary schools in Nusa Penida.

Lickona [15] considered the character education to be a broad umbrella that includes various approaches to building good character. THK and Ecotourism is one of the characters building approaches that is closely related to the conditions of education in Nusa Penida. So, the researcher considers it important to study theoretically the elements of character education in the THK and Ecotourism approaches.

\section{METHOD}

This study used a qualitative approach with descriptive qualitative methods. The reason researchers used descriptive qualitative methods because of several considerations include: this research is conceptual in describing the theory, describing things as they are, and the data collected is derived from observations and in-depth interviews. This research was conducted on Nusa Penida Island on 12-29 July 2018. The selection of research locations was based on information gathered from the literature regarding the implementation of ecotourism in Nusa Penida.

The procedure of this research begins with compiling interview and observation guidelines. Observations were made by directly observing the activities of grade 4-6 elementary schools in Nusa Penida relating to the character of environmental care for 17 days. The subjects of this study were two teachers, two principals, three students and one tourism agent. 
The focus of the study is to find elements of the character of environmental care in the concept of THK and Ecotourism. Data collection techniques are carried out by collecting primary and secondary data. Primary data is obtained through observations and interviews with principals, teachers, students and tourism actors. While secondary data is obtained through rules, learning media, and documentation of the implementation of THK and Ecotourism.

The results of the data obtained were analyzed by three ways based on Miles and Huberman [16] they are: data reduction, data display, and conclusion drawing. there are several criteria used to check data validity, including; credibility, triangulation, referential adequacy, transferability, dependability, and confimability [17].

\section{RESUlTS AND DisCUSSIONS}

\section{A. Result}

The research on the implementation of THKbased environmentally caring character education and Ecotourism in Nusa Penida revealed that THK and Ecotourism have elements with an approach that provides climate to elementary students in Nusa Penida to be close and love the nature.

\section{Environmental Care Character Based on THK}

Environmental care character is the attitude and action that always try to prevent the narural damage by developing the efforts to repair the damage and distraction in the nature [3]. Then, THK is the three causes of happiness which inside it there are Parhyangan, Pawongan dan Palemahan. The research results showed the reference of environmental care character education based on THK at Nusa Penida, those are:

\section{a. Parhyangan}

The implementation of Parhyangan refers to the meaning of a harmonious relationship between humans and God. Environmental care characters implemented through the Parhyangan concept are students who are accustomed to having a sense of responsibility in the school temple. The school temple as a manifestation of the relationship between students and God requires a variety of means of offering. One of the usual means of offerings by students is by bringing the flowers.

When using flowers as offerings, students take the flowers at school. The habit of students who use flowers as a form of offering to God Almighty, gives awareness that students must plant, care for and use flowers wisely.

\section{b. Pawongan}

The implementation of Pawongan refers to a harmonious relationship between humans and other humans. Wiana considered human strength to be in a life together to unite various kinds of potential possessed by each person [17].

The environmental care character implemented through the concept of Pawongan is leadership attitude which belongs to student in organizing their friends to do natural preservation activity.

Every once a week, the students of Elementary schools in Nnusa Penida have responsibility to keep the environment around the Pura in the village. In doing that activity, students organize themselves to divide the groups by their own jobs and functions. In organizing the cleanliness activity at the Village Pura, teachers teach students to behave independently and be responsible in their daily activity. So, the awareness of environmental care can grow in students' mind.

\section{c. Palemahan}

Palemahan is part of THK which has a harmonious relationship between humans and the environment. The meaning of the environment in the character of caring for the environment is the ability of students to be able to respond to the surrounding environmental problems.

The implementation of palemahan in the practice of character education on environmental care in schools is school cleaning activities carried out before starting learning. Although Palemahan is understood with the same concept by all elementary schools in Nusa Penida, in practice it has different attitudes.

Palemahan in the practice of learning emphasizes on giving an understanding of the Balinese cosala (spatial layout). This is to foster the character of environmental care that starts from a spatial system that does not damage the natural environment.

\section{B. Environmental Care Character Based on Ecotourism}

Ecotourism is a concept that was born by upholding the principles of local values, including THK. Ecotourism in Nusa Penida is an activity built on the school collaboration with several non-provit organizations such as Friends of National Park (FNPF) Nusa Penida and Trash Hero Nusa Penida.

Ecotourism implementation focuses on the professional character in managing the environment. Like the character of cooperation and tolerance that is built through cross-cultural. In addition, students' openness to environmental knowledge taught by tourists gives character. Confidence in local wisdom in their environment. Although Ecotourism upholds local values, there are several ecotourism principles that have stood alone according to the characteristics of ecotourism including:

\section{a. Environment}

The activity of environmental care characters intended for elementary students in Nusa Penida is to make various forms of crafts from environmentally 
friendly materials such as coconut milk. In addition, environmental care activities carried out encourage students to have curiosity regarding the types of folra and fauna species.

Ecotourism activities related to cleaning beaches and gardens are held every Monday in afternoon. Participants involved in this activity were elementary students in Nusa Penida and international volunteers.

\section{b. Development}

The implementation of the character of environmental care in the aspect of development is that students are trained to have an open attitude towards changes in Science and Technology to be able to preserve nature.

The innovations of wasteful things become powerful items should be taught frequently and consequently to the elementary students in Nusa Penida. Furthermore, organic and organic waste management gives students a new understanding of the natural environment. The concept of ecotourism on the aspect of development has a quiz program related to environmental topics. This encourages students to have a competitive attitude.

\section{c. Experience}

The implementation of ecotourism gives the widest space for everyone to get involved. This allows the international community to be involved in the implementation of ecotourism. Social skills in interacting and collaborating with people who have different cultures.

The concept of Ecotourism with an environmental care character indirectly requires students to have an adaptive attitude towards existing social conditions. It makes students to have experiences and learn about foreign cultures and languages and also it will make students to become more competent and be able to accept each person regardless of their background.

\section{B. Discussions}

Based on the presentation of the data, the following are the results of data analysis based on facts found when revealing the implementation of THK based on environmental care characters and ecotourism. The analysis is based on the variables that are divided into two types, those are: the character of environmental care based on THK and the character of ecotourism based on the environment.

THK is a fundamental concept for the life of Balinese people, especially elementary students in Nusa Penida. So, in the development of ecotourism refers to the concept of THK. The difference in the implementation of THK with Ecotourism in environmental care character education at Nusa Penida Elementary School is the time and the people who implement it.
The concept of THK as an environmentally caring character education seems to be implemented in Nusa Penida Elementary School. This is evidenced by the existence of the school temple as parahyangan, the school organization as pawongan, and the school environment as palemahan.

The character value of environmental care that is contained in the aspect of disaster is the attitude of being responsible for caring for plants and school plants as a means of offering. Whereas, the value of the character of environmental care contained in the aspect of pawongan is the attitude of cooperation, leadership and independence. The value of the environmentally caring character contained in the aspect of palemahan is a caring attitude towards the environment and a sense of confidence in the natural potential contained in the area.

Ecotourism is a concept that is carried out outside school activities but still in relation to inter-school collaboration with the tourism doers. The character value of environmental care contained in environmental aspects is that students have responsive and innovative attitudes toward existing natural resources. The character value of environmental care contained in the aspect of development is the open attitude of science and technology. The character value of environmental care contained in the aspect of experience is that students have a plural attitude in accepting culture and maximizing social attitudes well.

The implementation of THK and Ecotourism is basically an embodiment of the development of environmental care characters. However, THK and Ecotourism have implementation from a different time and authority perspective. THK focuses more on the role of students as school communities that are close to traditional values, while ecotourism focuses on the role of students as a community that is aware of the potential possessed by their regions.

Fostering the character of environmental care based on THK and Ecotourism is considered quite comprehensive in its implementation in Nusa Penida. As Dunkley explained, personal personal life, prior experience, and the wider socio-cultural context will also have a strong influence on perceptions, motivations, and actions produced on the environment [10].

\section{CONCLUSION}

THK and Ecotourism already have elements of environmental care character education applied by schools. Although it is not implemented as a program, exemplary, habits and attention to the character education on environmental care that have been maximally endeavored.

The implementation of environmental care character education based on THK refers to the elements of parahayangan, pawongan and palemahan. 
In parahayangan, it contains elements of the character of environmental care based on the values of piety, responsibility, harmony and caring that are practiced through the Pura in the school. In parwongan contains elements of the character of environmental care based on the values of leadership, responsibility, caring, fair, and open practiced through the media of school organizations. In the translation contains elements of the character of caring for the environment based on creative values, reasoning, responsibility, caring, cleanliness, and healthy practiced through the school's natural environment media.

The implementation of ecotourism-based environmental care character education for elementary school students in Nusa Penida is manifested in the elements of environment, development and experience. In the environment contains elements of value-based environmental care characters.

\section{ACKNOWLEDGMENT}

My great thanks to the principal of State Elementary Schools at Nusa Penida (SDN 2 PED dan SDN 4 PED), and all tourism doers at Nusa Penida for granting permission to conduct this research, Also my great thanks to Dr. Amat Jaedun, M.Pd. for the guidance and direction in this research.

\section{REFERENCES}

11] Afriza L. Kartika T, Riyanti A. "Pengembangan Ekowisata Berbasis Masyarakat (Community Based Ecotourism) Dalam Rangka Mengentaskan Kemiskinan Di Desa Karangsong Kabupaten Indramayu". Jurnal Sains Terapan Pariwisata Vol.3, No. 1. pp 20-34. 2007.

[2] Anderson, Vince; Datta, Ranjan; Dyck, Shannon; Kayira Jean and McVittie, Janet. "Meanings and implications of culture in sustainability education research". The Journal of Environmental Education. 47:1. Pp 1-18, DOI: 10.1080/00958964.2015.1056077. 2016.

[3] Kemendiknas. Bahan Pelatihan : Penguatan Metodologi Pembelajaran Berdasarkan Nilai-Nilai Budaya untuk membentuk daya saing dan Karakter Bangsa. Jakarta: Badan Penelitian dan Pengembangan Pusat Kurikulum. 2010.
[4] Kimmel, James R.. Ecotourism as Environmental Learning. The Journal of Environmental Education, 30:2, 40-44, DOI: 10.1080/00958969909601869. 1999.

[5] Lickona, Thomas. Eleven Principles of Effective Character Education, Journal of Moral Education, 25:1, 93-100, DOI: 10.1080/0305724960250110. 1996.

[6] Miles, M. B., \& Huberman, A. M. Qualitative Data Analysis: An Expanded Sourcebook. Thousand Oaks, CA: Sage Publications. Moleong, Lexy J. (2007) Metodologi Penelitian Kualitatif. Bandung: PT Remaja Rosdakarya Offset. 1994.

[7] Moleong, Lexy J. Metodologi Penelitian Kualitatif. Bandung: Penerbit PT Remaja Rosdakarya Offset. 2007.

[8] Muhaimin. Membangun Kecerdasan Ekologis Model Pendidikan untuk Meningkatkan Kompetensi Ekologis. Bandung: Penerbit Alfabeta. 2015.

[9] Nugroho, Iwan. Ekowisata dan Pembangunan Berkelanjutan. Yogyakarta: Pustaka Pelajar. 2011

[10] Dunkley, Ria Ann. Learning at eco-attractions: Exploring the bifurcation of nature and culture through experiential environmental education. The Journal of Environmental Education. VOL $\quad 0, \quad$ NO. $0, \quad 1-9$ http://dx.doi.org/10.1080/00958964.2016.1164113. 2016

[11] Sharpley, Richard. Ecotourism: A Consumption Perspective, Journal of Ecotourism, 5:1-2, 7-22, DOI: 10.1080/14724040608668444. 2006

[12] Sponsel, Leslie E. Cultural Ecology and Environmental Education, The Journal of Environmental Education, 19:1, 31-42, DOI: 10.1080/00958964.1987.10801958. 1987.

[13] Sudarsana, I Ketut. Optimalisasi Pemahaman Ajaran Tri Hita Karana Dalam Meningkatkan Karakter Siswa Sekolah Dasar (Perspektif Psikologi Pendidikan). Prosiding Seminar Pendidikan Dasar. Denpasar: Jayapangus Press. 2017.

[14] Sudira, Putu. Praksis Ideologi Tri Hita Karana Dalam Pembudayaan Kompetensi Pada SMK Di Bali. Disertasi. Pascasarjana Universitas Negeri Yogyakarta. 2011.

[15] Thwaites, Rik; Lipscombe, Neil dan Smith ; Emma. (2002). Providing Education in a Growth Industry. Journal of Teaching in Travel \& Tourism, 2:1, 81-97, DOI: 10.1300/ J172v02n01_05. 2002.

[16] Urbanus, I Nyoman dan Febianti. Analisis Dampak Perkembangan Pariwisata Terhadap Perilaku Konsumtif Masyarakat Wilayah Bali Selatan. Jurnal Kepariwisataan Dan Hospitalitas. Vol. 1, No. 2, November 2017.

[17] Wiana, Ketut. Tri Hita Karana Menurut Konsep. Surabaya: PARAMITA. 2007. 